\title{
Purification and Properties of Asparaginase from the Testa of Immature Seeds of Pea (Pisum sativum L.)
}

\author{
Eliana P. Chagas and Ladaslav Sodek* \\ Departamento de Fisiologia Vegetal, Instituto de Biologia, Universidade Estadual de Campinas, Caixa Postal \\ 6109, CEP 13087-970, Campinas - SP, Brazil
}

\begin{abstract}
A $K^{+}$-dependent asparaginase (E.C. 3.5.1.1.) was purified 1328-fold from the testas of immature pea seeds (Pisum sativum L., var. Bolero) and characterized. Antibodies raised against purified asparaginase cross-reacted with the putative asparaginase band in Western blot analyses of semi-purified extracts. However, for crude extracts of pea testas, a cross-reaction was obtained with at least four protein bands, one of which was asparaginase protein. Affinity-purified antibodies to the four strongest bands of crude extracts were fairly specific for the bands from which they were purified, suggesting a mixture of specific antibodies. The $M_{r}$ of asparaginase was 69,000 by Sephacryl 200 chromatography and also by mobility on native PAGE relative to BSA. There was no evidence for dissociation into subunits on SDS-PAGE, suggesting a monomeric protein of $M_{r} 69,000$. Other properties include an apparent $\mathrm{Km}$ of $2.4 \mathrm{mM}$, pI between 4.5 and 5, and competitive inhibition by aspartate and glycine.
\end{abstract}

Key words: Pisum sativum, asparaginase, purification, properties

\section{INTRODUCTION}

Asparagine predominates in the transport of nitrogen in many legumes studied so far and constitutes an important source of reduced nitrogen for developing seeds (Sieciechowicz et al., 1988). In developing pea seeds, it is initially metabolized in the seed coats (Murray \& Kennedy, 1980; Murray \& Cordova-Edwards, 1984) giving rise to ammonia, alanine and glutamine in the endosperm fluid. As the cotyledons start growing, the cotyledons themselves develop a capacity for metabolizing asparagine (Atkins et al., 1975). Indeed, isolated pea and soybean cotyledons grow in culture with asparagine as sole source of nitrogen (Thompson et al., 1977; Lea et al., 1979; Haga \& Sodek, 1987).

There are two known routes for asparagine catabolism. The first, catalysed by asparagine transaminase, involves the transamination of the amino group to form 2-oxosuccinamic acid and appears to be important in green leaves where it may play a role in photorespiration (Atkins et al., 1983; Murray et al., 1987; Joy, 1988). The second route involves the release of ammonia from the amide group in a reaction catalysed by asparaginase. This enzyme was first detected in the developing seeds of Lupinus albus (Atkins et al., 1975). Two forms of the enzyme have been identified. A $\mathrm{K}^{+}$-independent form found in $L$. arboreus (Lough et al., 1992a; Chang \& Farnden, 1995) and L. polyphyllus (Lea et al., 1978) and a

* Author for correspondence 
$\mathrm{K}^{+}$-dependent form found in Pisum sativum and several other legume species, including other Lupinus species (Sodek et al., 1980). Work with antibodies to the $\mathrm{K}^{+}$-independent form from $L$. polyphyllus revealed no cross-reaction with either pea ASNase or a number of varieties of Lupinus containing the $\mathrm{K}^{+}$-dependent enzyme, suggesting that the two forms of ASNase are immunologically distinct (Lea et al., 1984).

The $\mathrm{K}^{+}$-independent form has been more thoroughly studied, perhaps in view of its greater stability. It was first purified from L. polyphyllus (Lea et al., 1978) where it was shown to have a $M_{r}$ of 72,000 with subunits of 38,000 . It was later purified from L. arboreus which revealed a $M_{r}$ of 75,000 (Chang \& Farnden, 1995). A cDNA clone for a truncated asparaginase protein of $M_{r} 32,775$ has been isolated from this species (Lough et al., 1992b) and subsequently the complete genomic sequence was obtained (Dickson et al., 1992). The $\mathrm{K}^{+}$-dependent ASNase has been partially purified from pea leaves (Sieciechowicz \& Ireland, 1989) and the seed coat of immature pea seeds (Sodek \& Lea, 1993). However, purification sufficient for raising antibodies has never been achieved nor is there any information available as to its subunit composition. The aim of this work was to purify ASNase sufficiently to raise antibodies and extend the characterization of this enzyme.

\section{MATERIALS AND METHODS}

Plant material: Pea plants (Pisum sativum L. cv. Bolero) were cultivated in field plots during the winter (May-August). Immature seeds were harvested when endosperm fluid was still present, before the rapid growth phase of the cotyledons. Isolated testas were stored frozen at $-20^{\circ} \mathrm{C}$.

Tissue extraction: Frozen testas were ground in a chilled mortar with $50 \mathrm{mM}$ Tris- $\mathrm{HCl} \mathrm{pH} 8.0$ buffer containing $50 \mathrm{mM} \mathrm{KCl}, 1 \mathrm{mM}$ dithiothreitol, $1 \mathrm{mM}$ PMSF and 10\% glycerol. The extract was centrifuged at $10,000 \times \mathrm{g}$ for $20 \mathrm{~min}$ and the supernatant used for purification or enzyme assay after desalting on a Sephadex G25 column.
Enzyme assay: Asparaginase (ASNase) (EC 3.5.1.1) was assayed by the ammonia-diffusion and phenol-hypochlorite method described previously (Sodek \& Lea, 1993).

Purification procedure: The purification of ASNase was based on that described by Sodek \& Lea (1993). Column dimensions were: Sephadex LH20 2.8 x 19 cm; DEAE-Sephacel $1.3 \times 5.3 \mathrm{~cm}$; Phenyl Sepharose $10 \mathrm{~mL}$; Sephacryl S-200 $2.6 \mathrm{x}$ $83 \mathrm{~cm}$; FPLC-Mono Q 0.5 x $5 \mathrm{~cm}$.

Kinetic studies: $K_{m}$ was determined from double reciprocal plots (Lineweaver-Burke) and inhibitor constants $\left(\mathrm{K}_{\mathrm{i}}\right)$ from secondary plots of slope from Lineweaver-Burke plots against inhibitor concentration.

Molecular weight: Estimates of molecular weight were made using the same Sephacryl S-200 column used during purification. The column was calibrated with blue dextran $(2,000,000 \mathrm{~g} / \mathrm{mol})$, catalase $(232,000 \mathrm{~g} / \mathrm{mol}), \quad \beta$-amylase $(200,000$ $\mathrm{g} / \mathrm{mol})$, alcohol dehydrogenase $(150,000 \mathrm{~g} / \mathrm{mol})$, BSA $(67,000 \mathrm{~g} / \mathrm{mol})$, carbonic anhydrase $(29,000$ $\mathrm{g} / \mathrm{mol})$, chymotypsinogen $(25,000 \mathrm{~g} / \mathrm{mol})$, ribonuclease A $(13,700 \mathrm{~g} / \mathrm{mol})$ and cytochrome c $(12,000 \mathrm{~g} / \mathrm{mol})$. For SDS-PAGE the standard protein mixture contained BSA $(67,000 \mathrm{~g} / \mathrm{mol})$, ovalbumin $(43,000 \mathrm{~g} / \mathrm{mol}) \quad$ chymotrypsinogen $(25,000 \mathrm{~g} / \mathrm{mol})$ and ribonuclease A $(13,700 \mathrm{~g} / \mathrm{mol})$.

Polyacrylamide gel electrophoresis: Native and SDS-PAGE were carried out using the Midget system (Hoeffer Sci. Inst.) with 10 and 13\% acrylamide gels, respectively. After electrophoresis, proteins were detected by silver staining (Oakley et al., 1980). Other details are as described previously (Sodek \& Lea, 1993).

Antibody preparation and western blot analysis: The most active fractions obtained after the FPLC MonoQ purification step were pooled, dialysed against distilled water, lyophilized and taken up in phosphate buffer saline (PBS) solution. An aliquot (containing $50 \mu \mathrm{g}$ of protein) was emulsified with Freund's complete adjuvant and injected subcutaneously into a rabbit. A second application, prepared with incomplete adjuvant was 
injected 3 weeks later. After 6 weeks, a blood sample was taken from the rabbit and the $\operatorname{IgG}$ fraction purified from the serum using ammonium sulphate precipitation followed by Protein-A Sepharose affinity chromatography, as described previously (Sodek \& Lea, 1993).

After electrophoresis, the proteins were transferred electrophoretically to a nitrocellulose membrane (Biotrace NT, Gelman), according to Towbin et al (1979), using the LKB-Pharmacia horizontal Multiphor Nova Blot system. A constant current of $0.8 \mathrm{~mA} / \mathrm{cm}^{2}$ was applied for $3 \mathrm{hr}$. Immunoprobing of the membrane was carried out as described previously (Sodek \& Lea, 1993).

In some Western blot analyses, antibodies were first purified by affinity to proteins of a primary blot, using a technique adapted from Buckeridge \& Reid (1994). After electrotransfer of proteins from a crude extract, the nitrocellulose membrane was divided into 3 parts. The first was probed and developed as usual to identify the position of the reacting proteins. The second was then sliced to isolate the regions containing each one of the reacting proteins. The cut pieces, after blocking with casein, were incubated separately overnight with the crude antibody, washed 3 times with Tris buffer saline containing Tween and finally placed overnight in $5 \mathrm{~mL}$ of $0.1 \mathrm{M}$ glycine, $\mathrm{pH}$ 2.5, to dissociate the antibody from the membrane. After adjusting the $\mathrm{pH}$ to 7 , the antibody was used to probe (overnight) the third part of the membrane, which was developed by the usual techniques.

\section{RESULTS}

Purification of asparaginase. Asparaginase was purified from the testas of immature seeds of Pisum sativum L. An over 1000-fold purification was acheived (Table 1). The plant material used as a source of the enzyme presented an average activity of $7 \mu \mathrm{mol} \mathrm{NH}{ }_{4}^{+} / \mathrm{h}$.g tissue (s.d.=2.2, $\mathrm{n}=6$ ). $\mathrm{K}^{+}$ions were included in both the extraction and assay buffers, in view of its known necessity for activity. $\mathrm{Ca}^{2+}$ ions were also included in the extraction buffer although preliminary tests indicated that they had no effect on activity whether present during extraction or in the assay. Nor did EGTA have any effect when included in the assay. Nevertheless, $\mathrm{Ca}^{2+}$ was used in the extraction buffer because it appeared to improve the recovery of activity during purification, especially at later stages.

A single activity peak was obtained during all purification steps involving chromatography, except for Sephacryl S-200 where a small fraction of the total activity (about $4 \%$ ) eluted ahead of the main peak. This fraction was discarded in the purification procedure described in Table 1. The purification step which produced the highest relative gain in specific activity was the treatment with ethanol (after its subsequent removal on Sephadex LH20). All purification steps produced an increase in specific activity despite the instability of the enzyme which diminished recovery. In fact, final recovery of activity was only $1 \%$.

Table 1. Purification of $\mathrm{K}^{+}$-dependent asparaginase from immature pea testas.

\begin{tabular}{|c|c|c|c|c|c|}
\hline Step & $\begin{array}{l}\text { Total volume } \\
(\mathrm{mL})\end{array}$ & $\begin{array}{l}\text { Protein } \\
(\mathrm{mg} / \mathrm{mL})\end{array}$ & $\begin{array}{l}\text { Specific activity } \\
\left(\text { umol. }^{-1} \cdot \mathrm{mg}^{-1}\right)\end{array}$ & $\begin{array}{l}\text { Purification } \\
\text { factor }\end{array}$ & $\begin{array}{c}\text { Recovery } \\
(\%)\end{array}$ \\
\hline Crude extract & 100 & 1.909 & 1.0 & 1 & 100 \\
\hline LH-20 & 21 & 0.262 & 10.1 & 10 & 30 \\
\hline DEAE-sephacel & 20 & 0.040 & 65.6 & 65 & 27 \\
\hline Phenyl-sepharose & 6 & 0.031 & 115.3 & 115 & 11 \\
\hline Sephacryl-S200 & 3.7 & 0.010 & 425.0 & 425 & 8 \\
\hline Mono-Q & 1 & 0.001 & 1328.0 & 1328 & 1 \\
\hline
\end{tabular}


Electrophoretic behaviour. After some of the purification steps, fractions with asparaginase activity were analysed by native and SDS-PAGE. Following chromatography on Mono-Q, the last purification step, where all activity eluted as a single peak, native PAGE of the peak fractions revealed the presence of two distinct protein bands (denominated B1 \& B2) with mobilities corresponding to $M_{r} 85,000$ and 69,000 (relative to BSA monomer and dimer) (Figure 1). Clearly, band B1 was present only in the leading fractions of the activity peak whereas band B2 was present in all the activity peak fractions. Furthermore, this band was strongest in the fraction containing the highest activity. This suggested that asparaginase activity was associated with the band B2 $\left(M_{r}\right.$ 69,000), but not with band B1.
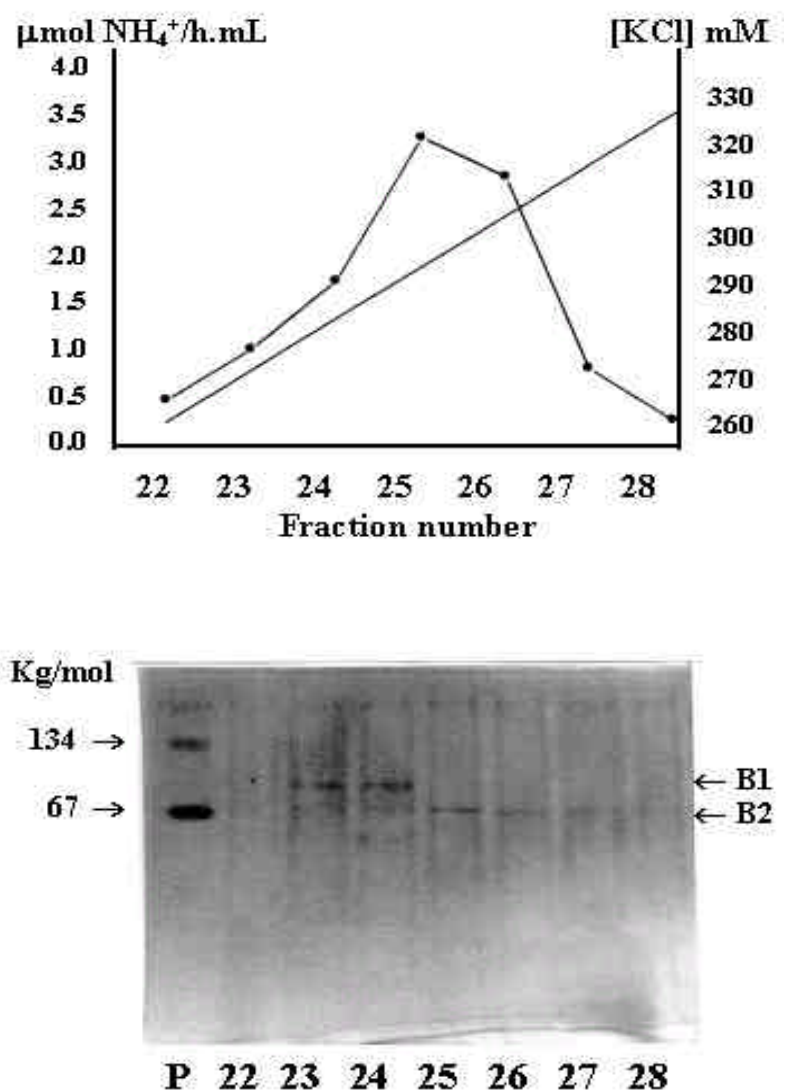

Figure 1 - Electrophoretic characterization of the ASNase activity peak obtained after chromatography on MonoQ. Upper: relative activities of fractions after Mono Q chromatography. Lower: Native PAGE of the respective peak fractions. $\quad \mathrm{P}=\mathrm{BSA}$ (monomer 67 $\mathrm{kDa}$, dimer $134 \mathrm{kDa}$ ) used as reference protein.
Despite the apparent difference in molecular weight of the two proteins, B1 and B2, identified by native PAGE, it was not possible to separate them by molecular sieve chromatography (Sephacryl S200), as used in the penultimate purification step. Although two peaks of activity were obtained from this column (figure 2), the first, with only $4 \%$ of the total activity, produced a slow-moving band, corresponding to a molecular weight of about 200,000, when analysed by native PAGE (Fig.2 lanes 19, 20). In any case, this activity was discarded during purification and would not be present in the extract used for Mono-Q chromatography that produced the B1 band. On the other hand, both the B1 \& B2 proteins were present in the main activity peak of the Sephacryl column, as revealed by native PAGE analysis of the peak fractions (lanes 29-36). However, both proteins were present in all the activity peak fractions without any indication of separation suggesting similarity in their molecular weights; therefore other physical properties must determine their separation by native PAGE.
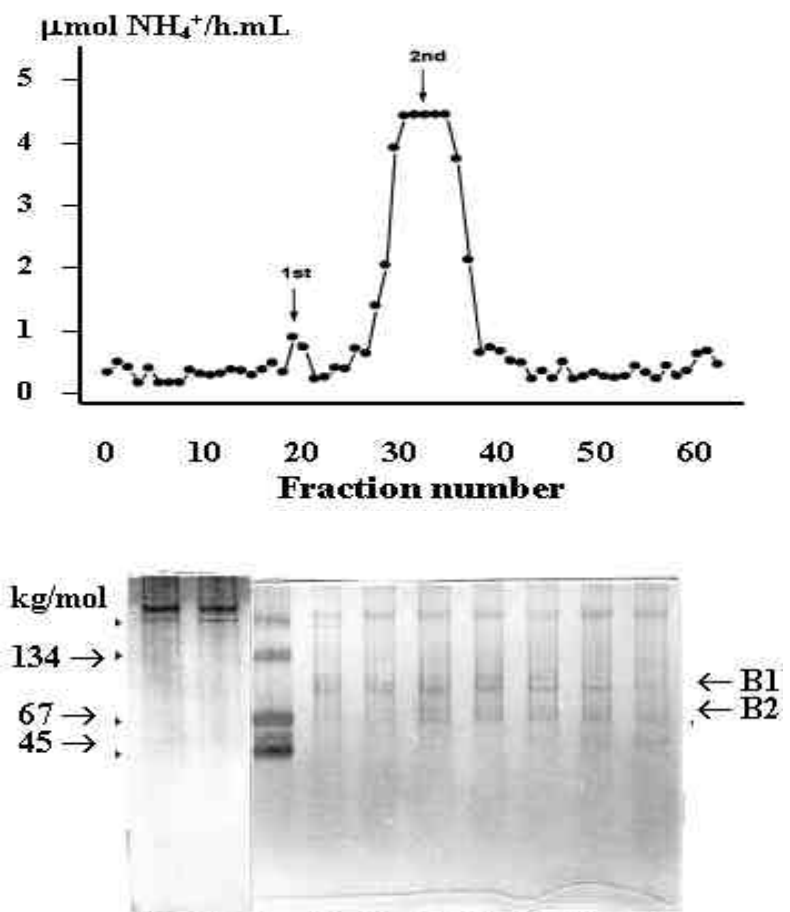

$\begin{array}{llllllllll}19 & 20 & P & 29 & 30 & 31 & 32 & 34 & 35 & 36\end{array}$

Figure 2 - Electrophoretic characterization of the ASNase activity peaks obtained after chromatography on Sephacryl S-200. Upper: relative activities of fractions after Sephacryl S-200 chromatography. Lower: Native PAGE of the respective peak fractions. $\mathrm{P}=\mathrm{BSA}$ (monomer $67 \mathrm{kDa}$, dimer $134 \mathrm{kDa}$ ) and ovalbumin $(45 \mathrm{kDa})$ used as reference proteins. 
In order to confirm that ASNase activity was indeed associated with band B2 rather than B1, activity of the enzyme was determined directly in the gel after electrophoresis. For this purpose, a fraction with high activity eluted from the PhenylSepharose column was applied to a native gel and, after electrophoresis, activity determined in gel slices by a semi-quantitative assay (Sodek \& Lea, 1993). The formation of aspartic acid in the assay, as analysed by TLC, was intense for slices taken from the region of the BSA monomer $\left(M_{r}\right.$ 67,000; used as a marker), which corresponded therefore, to the B2 band $\left(M_{r} 69,000\right)$ (data not shown).

The B1 \& B2 proteins, obtained by chromatography on Mono-Q, were also submitted to SDS-PAGE analysis. From Figure 3 it may be seen that the $\mathrm{B} 1$ protein dissociated into subunits of about $M_{r}$ 18,000, whereas the B2 $\left(M_{r} 69,000\right)$ protein apparently did not dissociate since only one band was seen in the same position as in native gels.

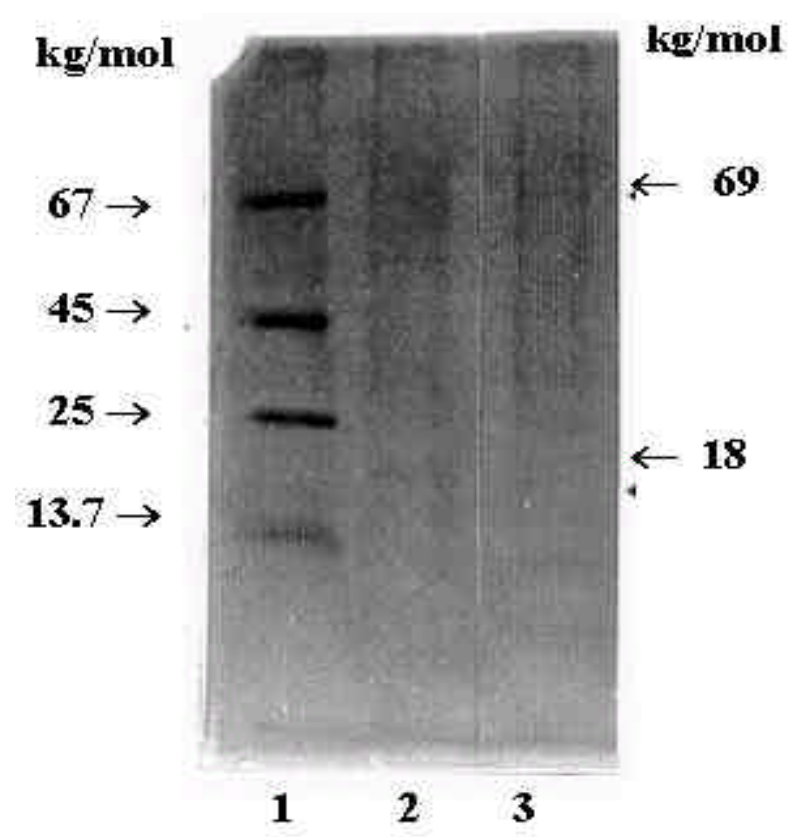

Figure 3 - SDS-PAGE analysis of specific ASNase peak fractions after MonoQ chromatography. 1Protein MW standards. 2- initial peak fraction, (corresponding to the $\mathrm{B} 1$ native PAGE protein band). 3- late peak fraction (corresponding to the $\mathrm{B} 2$ native PAGE protein band).
Properties of asparaginase. Partially purified ASNase revealed Michaelis and Menten kinetics with an apparent $\mathrm{K}_{\mathrm{m}}$ of $2.4 \mathrm{mM}$. The enzyme was inhibited competitively by Gly and Asp $\left(\mathrm{K}_{\mathrm{i}}=7.7\right.$ $\mathrm{mM}$ and $11 \mathrm{mM}$, respectively). Information on the pI value was obtained after isoelectric focalization in the Rotorfor ${ }^{\mathrm{TM}}$ (Pharmacia) system, where ASNase activity was found in fractions corresponding to a $\mathrm{pH}$ of 4.5 to 5.0.

Western blots. Western blots using crude extracts and a partially purified fraction (Phenyl-Sepharose step) revealed six and two bands, respectively, when probed with the antibody produced against purified asparaginase (Figure 4). The four strong bands of the six identified in the crude extract by the antibody (Fig.4 -A) are denominated B1 (two closely-running bands), B2 (putative ASNase band), and B3. Two weak band were seen, one running between $\mathrm{B} 2$ and $\mathrm{B} 3$ and the other near the top of the gel. The two bands obtained with the partially purified fraction (Fig.4 -B), according to this nomenclature, correspond to B1 and B2.

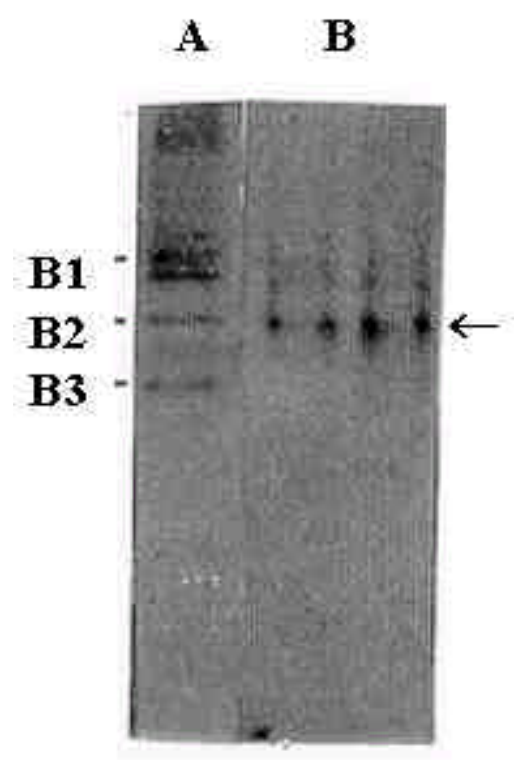

Figure 4 - Western Blot of extracts from immature pea seed testas using the antibody raised against purified ASNase as probe. $\mathrm{A}=$ crude extract $\mathrm{B}=$ partially purified extract (Phenyl-Sepharose). Band B2 corresponds to ASNase. 
Since the antibody reacted with proteins other than those running in the position of ASNase when using crude extracts, further tests were performed in order to determine whether these additional bands resulted from poor antibody specificity or to the presence of other forms of ASNase in the crude extracts. Here, the Western blot system was used to "purify" the antibody

through its affinity for each of these protein bands. When the antibody that attached itself to each band of the blots was dissociated from the complex and used as a probe in a separate Western blot of the crude extract, a certain degree of specificity for each antibody was observed (fig. 5). Thus, antibody taken from the two B1 bands reacted most strongly with the same bands in the second blot, as did the B2 and B3 bands. There was, however, a weak reaction with other bands in all cases except for the antibody removed from the B3 band where no trace of reaction with the other bands could be observed.

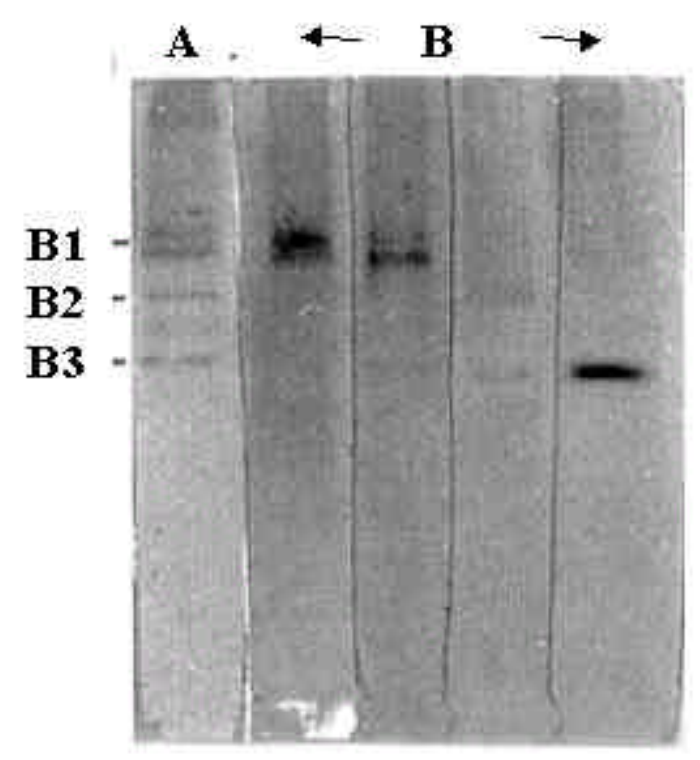

Figure 5 - Western Blot of crude extracts from immature pea testas using affinity purified ASNase antibody as probe. $\mathrm{A}=$ Initial blot with crude extract. $\mathrm{B}=$ Identical blot probed with antibodies purified by affinity in a primary blot: using antibody dissociated from 1. the upper B1 band; 2. the lower B1 band; 3. the B2 (putative ASNase) band; 4. the B3 band.

\section{DISCUSSION}

Asparaginase was purified from the testas of immature seeds of Pisum sativum L., essentially as described by Sodek \& Lea (1993). An over 1000fold purification was achieved with a specific activity of $1328 \mu \mathrm{mol}^{-1} \cdot \mathrm{mg}^{-1}$ protein (Table 1). Although the purification factor was far superior to that obtained by Sodek \& Lea (1993), the specific activity was only marginally improved. The high instability of the enzyme would appear to be responsible for this discrepancy. Indeed, final recovery of activity was only $1 \%$.

The asparaginase from immature pea seeds has previously been characterized as being potassiumdependent (Sodek et al., 1980). The Km was 2.4 $\mathrm{mM}$, somewhat lower than that reported by Sodek et al (1980), using a different assay, but nevertheless in the general range for $\mathrm{K}^{+}$-dependent ASNases, that is, $2.5-4.9 \mathrm{mM}$ from pea leaf (Sieciechowicz \& Ireland, 1989) and $2.7 \mathrm{mM}$ from winged bean seeds (Chapleo \& Hall, 1989). It is noteworthy that the $\mathrm{Km}$ of $\mathrm{K}^{+}$-independent ASNases are significantly higher (Chang \& Farnden, 1995; Lea et al., 1978), in the range 6 to $12 \mathrm{mM}$. The ASNase from L. albus, with a $\mathrm{Km}$ of the order 10 - $12 \mathrm{mM}$ (Atkins et al., 1975), would appear to be an exception, since this enzyme was later reported to be $\mathrm{K}^{+}$-dependent (Sodek et al., 1980). Some caution is necessary when comparing $\mathrm{K}_{\mathrm{m}} \mathrm{s}$ however, in view of the findings of Sieciechowicz \& Ireland (1989) that higher $\mathrm{K}_{\mathrm{m}} \mathrm{S}$ may result from inactivation of the enzyme during assays at lower concentrations of Asn. Stabilizing the enzyme during assay by the addition of $10 \%$ glycerol avoids this problem and leads to lower $\mathrm{K}_{\mathrm{m}}$ values.

Competitive inhibition by aspartate, one of the reaction products, suggests that the reaction mechanism (Cleland, 1963) involves an ordered liberation of products from the catalytic site, with aspartate leaving last. Kinetic data for ammonium as inhibitor, which might confirm this finding, was not possible due to the assay being based on ammonium formation. The competitive inhibition observed with glycine was also reported for the $\mathrm{K}^{+}$independent ASNase from L. arboreus (Chang \& Farnden, 1995). 
The $M_{r}$ of 69.000 was in agreement with that found for the pea testa ASNase by Sodek et al (1980), though Sodek \& Lea (1993) subsequently reported a lower value $(61,000 \mathrm{Da})$. The $\mathrm{K}^{+}$-dependent ASNase from pea leaves was reported to have a $M_{r}$ of 58,000 (Sieciechowicz \& Ireland, 1989). In any case, the $M_{r}$ of the $\mathrm{K}^{+}$-dependent enzyme from pea appears to be marginally lower than the $\mathrm{K}^{+}$independent enzyme from Lupinus species, reported as 71,000 for L. polyphyllus (Sodek \& Lea, 1993), and 75,000 for L. arboreus

(Chang \& Farnden, 1995).

Although the subunit structure for the $\mathrm{K}^{+}-$ independent enzyme of $L$. arboreus (Lough et al., 1992a) and L. polyphyllus (Sodek \& Lea, 1993) was characterized as 2 subunits with a $M_{r}$ of 35-36 $\mathrm{kDa}$, no comparable data are available for the $\mathrm{K}^{+}$dependent ASNase. In this study, there was no evidence for the dissociation of the enzyme into subunits. Rather, the SDS-PAGE data suggest the enzyme to be composed of a single polypeptide of 69,000 Da.

Another novel feature of this study was the identification of a high MW ASNase (ca. $M_{r}$ 200,000). This enzyme was not further characterized, and in any case it represented only a very small fraction of total ASNase activity.

The $p I$ value of 4.5 - 5.0 inferred from the isoelectric focusing experiment for ASNase is close to the value of 5.2 calculated from the cloned gene of Arabidopsis thaliana by Casado et al (1995) and the value of 4.5 for $\mathrm{K}^{+}$-independent ASNase from L. arboreus (Lough et al., 1992a).

Attempts to obtain the $\mathrm{N}$-terminal sequence of the purified protein were unsuccessful, suggesting a possible blocked $\mathrm{N}$-terminal.

The antibody raised against the purified ASNase showed poor specificity when used as a probe in Western blot analysis of crude extracts. As well as the ASNase band itself, several others crossreacted with the antibody. Since the protein doublet denominated B1 was difficult to separate from the ASNase protein, it is not surprising that antibodies for this protein were present in the preparation. Attempts to purify the antibody by stripping them off their respective proteins from the blots and using them separately as probes in identical blots of the crude extracts resulted in a preferential if not specific reaction with the original proteins. This suggests that the antibody preparation is a mixture of specific antibodies rather than the crude extract being composed of several forms of the ASNase protein. However, there is no explanation for the origin of the highly specific antibody to band B3, since this protein was absent from the preparation used to generate the antibody. The antibody would have to be used with caution as a probe for ASNase protein.

\section{ACKNOWLEDGEMENTS}

This work received financial support from FAPESP. EPC thanks CAPES for a scholarship.

\section{RESUMO}

Uma asparaginase dependente do $\mathrm{K}^{+}$(E.C. 3.5.1.1.) foi purificada 1328 vezes a partir de testas de sementes imaturas de ervilha (Pisum sativum L., var. Bolero) e caracterizada. Anticorpos obtidos a partir da asparaginase purificada, usados como sonda em ensaios tipo "Western blot", reagiram com a banda da asparaginase de extratos semipurificados. Entretanto, em ensaios realizados com extratos brutos de testas de ervilha, uma reação foi obtida com pelo menos 4 proteínas, entre elas a da asparaginase. $\mathrm{O}$ uso de anticorpos purificados por afinidade pelas 4 bandas mais evidentes do extrato bruto demonstraram um alto grau de especificidade para com as bandas de proteína das quais foram purificadas, indicando uma mistura de anticorpos específicos. A posição de eluição da atividade de asparaginase em Sephacryl S-200, bem como a sua mobilidade em PAGE não-denaturante relativo à BSA, sugere uma $M_{r}$ 69.000. Em análise realizada por SDS-PAGE não foi obtida nenhuma evidência para a dissociação da proteína em subunidades, sugerindo que a proteína seja monomérica com $M_{r}$ 69.000. Outras propriedades incluem um $\mathrm{Km}$ apparente de $2,4 \mathrm{mM}, p \mathrm{I}$ entre 4,5 e 5, e inibição competitiva pelo aspartato e pela glicina. 


\section{REFERENCES}

Atkins, C. A.; Pate, J. S. and Sharkey, P. J. (1975), Asparagine metabolism - key to the nitrogen nutrition of developing legume seeds. Plant Physiol., 56, 807-812

Atkins, C. A.; Pate, J. S.; Peoples, M. B. and Joy, K. (1983), Amino acid transport and metabolism in relation to the nitrogen economy of a legume leaf. Plant Physiol., 71, 841-848

Buckeridge, M. S. and Reid, J. S. (1994), Purification and properties of a novel $\beta$-galactosidase or exo-(14)- $\beta$-D-galactanase from the cotyledons of germinated Lupinus angustifolius L. seeds. Planta, 192, 502-511

Casado, A.; Caballero, J. L.; Franco, A. R.; Cardenas, J.; Grant, M. R. and Muñoz-Blanco, J. (1995), Molecular cloning of the gene encoding the Lasparaginase gene of Arabidopsis thaliana. Plant Physiology, 108, 1321-1322

Chang, K. S. and Farnden, K. J. F. (1981), Purification and properties of asparaginase from Lupinus arboreus and Lupinus angustifolius. Arch. Biochem. Biophys., 208, 49-58

Chapleo, S. and Hall, J. L. (1989), Effects of applied nitrogen upon aspects of nitrogen metabolism and transport in developing nodulated winged bean plants. Physiol. Plant., 77; 359-368

Cleland, W. W. (1963), The kinetics of enzymecatalysed reactions with two or more substrates or products. III. Prediction of initial velocity and inhibition patterns by inspection. Biochim. Biophys. Acta, 67, 188-196

Dickson, J. M. J. J.; Vincze, E.; Grant, M. R.; Smith, L. A.; Rodber, K. A.; Farnden, K. J. F. and Reynolds, P. H. S. (1992), Molecular cloning of the gene encoding developing seed L-asparaginase of Lupinus angustifolius. Plant Mol. Biol., 20, 333-336

Haga, K. I. and Sodek, L. (1987), Utilization of nitrogen sources by immature soybean cotyledons in culture. Ann. Bot., 9, 597-601

Joy, K. W. (1988), Ammonia, glutamine and asparagine: a carbon-nitrogen interface. Can. J. Bot., 66, 2103-9

Lea, P. J., Fowden, L. and Miflin, B. J. (1978), The purification and properties of asparaginase from Lupinus species. Phytochemistry, 17, 217-222

Lea, P. J.; Festenstein, G. N.; Hughes, G. R. and Miflin, B. J. (1984), An immunological and enzymological survey of asparaginase in seeds of Lupinus. Phytochemistry, 23, 511-514

Lea, P. J.; Hughes, J. S. and Miflin, B. J. (1979), Glutamine- and asparagine-dependent protein synthesis in maturing legume cotyledons cultured in vitro. J. Exp. Bot., 30, 529-37
Lough, T. J.; Chang, K. S.; Carne, A.; Monk, B. C.; Reynolds, P. H. S. and Farnden, K.J.F. (1992a), LAsparaginase from developing seeds of Lupinus arboreus. Phytochemistry, 31, 1519-27

Lough, T. J.; Reddington, B. D.; Grant, M. R.; Hill, D. F.; Reynolds, P. H. S. and Farnden, K. J. F. (1992b), The isolation and characterization of a cDNA clone encoding L-asparaginase from developing seeds of lupin (Lupinus arboreus) Plant Mol. Biol., 19, 391399

Murray, D. R. and Kennedy, I. R. (1980), Changes in activities of enzymes of nitrogen metabolism in seed coats and cotyledons during embryo development in pea seeds. Plant Physiol., 66, 782-786

Murray, D. R. and Cordova-Edwards, M. (1984), Amino acid and amide metabolism in the hulls and seeds of developing fruits of garden pea, Pisum sativum. II. asparagine. New Phytol., 97, 253-260

Murray, A. J. S.; Blackwell, R. D.; Joy, K. W. and Lea, P. J. (1987), Photorespiratory-N donors, aminotransferase specificity and photosynthesis in a mutant of barley deficient in serine - glyoxylate aminotransferase activity. Planta, 172, 106-113

Oakley, B. R.; Kirsch, D. R. and Morris, N. R. (1980), A simplified ultrasensitive silver stain for detecting proteins in polyacrylamide gels. Analyt. Biochem., 105, 361- 363

Sieciechowicz, K.; Joy, K. W. and Ireland, R. J. (1988), The metabolism of asparagine in plants. Phytochemistry, 27, 663-671

Sieciechowicz, K. and Ireland, R. J. (1989), Isolation and properties of an asparaginase from leaves of Pisum sativum. Phytochemistry, 28, 2275-79

Sodek, L.; Lea, P. J. and Miflin, B. J. (1980), Distribution and properties of potassium-dependent asparaginase isolated from developing seeds of Pisum sativum and other plants. Plant Physiol., 65, 22-26

Sodek, L. and Lea, P. J. (1993), Asparaginase from the testa of developing lupin and pea seeds. Phytochemistry, 34, 51-56

Thompson, J. F.; Madison, J. T. and Muenster, A. M. E. (1977), In vitro culture of immature cotyledons of soya bean (Glycine max L. Merr). Ann. Bot., 41, 29-39

Towbin, H.; Staehelin, T. and Gordon, J. (1979). Electrophoretic transfer of proteins from polyacrylamide gels to nitrocellulose sheets: procedure and sample application. Proc. Nat. Acad. Sci., USA, 76, 4350-4
Received: December 13, 1999; Revised: August 25, 2000; Accepted: November 22, 2000 
